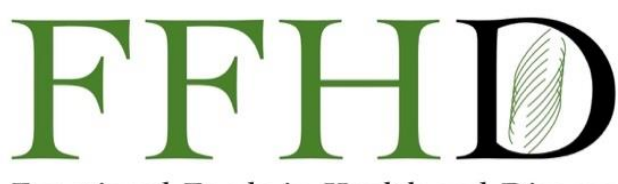

Functional Foods in Health and Disease

\title{
Different impacts of plant proteins and animal proteins on human health through altering gut microbiota
}

\author{
Sunil Christudas, Ramya Devi Devaraj, and Baojun Xu*
}

Food Science and Technology Programme, Beijing Normal University-Hong Kong Baptist University United International College, Zhuhai, Guangdong 519087, China

*Corresponding Author: Prof. Baojun Xu, Ph. D Program of Food Science and Technology, Beijing Normal UniversityHong Kong Baptist University United International College, 2000, Jintong Road, Tangjiawan, Zhuhai 519087, Guangdong, China.

Submission Date: February 25 ${ }^{\text {th }}, 2020$; Acceptance Date: May 14 ${ }^{\text {th }}, 2020$; Publication Date: May $18^{\text {th }}, 2020$

Please cite this article as: Christudas S., Devaraj R., Xu B. Different impacts of plant proteins and animal proteins on human health through altering gut microbiota. Functional Foods in Health and Disease. 2020; 10(5): 228-241. DOI: 10.31989/ffhd.v10i5.699

\section{ABSTRACT}

Dietary proteins exert a wide range of nutritional and biological functions. Apart from their nutritional roles as the source of amino acids for protein synthesis, they take part mainly in the regulation of food intake, blood pressure, bone metabolism, glucose and lipid metabolism, and immune functions. The interaction of dietary proteins with the gastrointestinal (GI) tract plays a chief role in determining the physiological properties of proteins. The enzymes protease and peptidase hydrolyze dietary protein to generate dipeptides, tripeptides, and amino acids in the lumen of the gastrointestinal tract. These products digested from dietary proteins are utilized in the small intestine by microbes. Moreover, the microbes also convert the macro and micronutrients from the diet into an enormous number of compounds that may have either beneficial or adverse effects on human health. The present review discusses the various impacts caused by both dietary plant and animal protein sources on microbiota in the GI tract.

Keywords: Animal protein; Plant protein; Dietary proteins; Gut microbiota; Human health.

CFFC 2020. This is an Open Access article distributed under the terms of the Creative Commons Attribution 4.0 License (http://creativecommons.org/licenses/by/4.0).

\section{INTRODUCTION}

Every organism needs protein to build and maintain muscles, bones, skin, tissues, and body functions. According to the Centers for Disease Control and Prevention, a woman needs 46 grams of protein and a man requires 56 grams of protein per day to maintain optimum health [1]. Among the different. proteins, dietary proteins from plant and animal sources provide essential nutrients. All 20 amino acids are present in such products of plant and animal sources, but the quantity varies. Considering the nutritional aspects of dietary proteins, they are considered essential sources of amino acids that provide energy and allow for protein synthesis. The dietary protein absorbed from the gut has a wide range of functions both nutritionally and biologically. The quality and function of proteins have been 
analyzed mainly on their ability to provide essential amino acids and support protein synthesis [2].

Proteins from animals are considered complete proteins, which provide all amino acids, [3] whereas, proteins from plant sources lack one or more amino acids [4]. Generally, plant proteins provide nutrients such as beta-carotene, dietary fiber, vitamin C, vitamin $E$, folic acid, iron, magnesium, and calcium. A person that consumes protein solely from animal sources has a greater chance of diseases related to heart and blood pressure, but this is not the case with from plant proteins [5]. Some epidemiological studies show that the risk of cardiovascular disease [6] and colorectal cancer [7] are higher following the regular consumption of red meat (beef and pork). However, meat remains an important component in the human diet because it contains high quantities of proteins, amino acids, fatty acids, minerals, and vitamins [3]. The major advantage of eating animal proteins is that they contain all 20 amino acids. Thus, plant proteins are generally taken in a combined form with animal proteins to satisfy the complete need for amino acids. This article reviews the key knowledge about the effects of plant and animal protein sources as well as their qualities and actions on microbiota in the GI tract.

\section{Dietary Protein Sources}

The dietary protein sources are mainly plant and animal sources. These sources have a complex mixture of proteins that influence physiologic regulation in different ways when consumed.

\section{Plant Proteins}

Cereals, pulses, soybeans, and seaweed are plant protein sources with varying complex characteristics.

\section{Cereal Proteins}

Cereals are the world's most important food crops which consists of seeds (rice, barley, oats, millet, sorghum, maize), flour (wheat, rye, maize), and flakes (barley, oats, maize). The metabolically active cereal proteins include mostly enzymes (protease inhibitors), which control various reactions, and storage proteins like albumins and globulins (glutelins and prolamins) which facilitate protein biosynthesis as building blocks during germination [8]. Several biological properties of cereal proteins have been reported. Especially, the hydrolyzed proteins and peptides from cereals showed potent antioxidant effects by scavenging the free radicals like DDPH, ABTS, hydroxyl radicals, followed by anti-inflammatory, and antiulcer activities [5]. Borneo and León [9] reported that a high consumption of whole-grain cereals is associated with a reduced risk of hypertension. Further, epidemiological studies have repeatedly shown that the risk for diabetes mellitus type II (T2DM) decreases with the increase in consumption of whole grains [10].

\section{Pulse Proteins}

Pulse proteins include dry peas, lentils, beans, and chickpeas from the edible seeds of legumes. In general, pulses contain 17-30\% of protein. The major proteins present in pulses are albumins, and globulins. Trypsin inhibitors and chymotrypsin inhibitors are the anti-nutritional factors present in the unprocessed seeds. Improper inactivation of the anti-nutritional factors during processing will lead to a decrease in protein digestibility. The digestibility of proteins determines its nutritional value [11]. Pulse consumption also improves serum lipid profiles and positively affects several other cardiovascular disease risk factors, such as blood pressure, platelet activity, and inflammation [12]. Dahl et al. [13] also reported that a number of nutrients and non-nutrient components of pulses contributed to a reduction of cancer risk.

\section{Soybeans}

Soybeans are an oilseed and one of the least expensive sources of dietary protein with many useful nutrients including proteins, carbohydrates, vitamins, and minerals $[14,15]$. They have a high protein content of $35-40 \%$ of dry weight with all amino acids being similar to animal protein except sulfur amino acids (methionine and cysteine). Thus, they are considered a good replacement for animal proteins [16]. Soy protein can lower cholesterol levels by modulating the LDL receptors in the liver [17]. However, when fed to hypercholesterolemic diabetic albino rats, pasta made of durum wheat added with defatted soy flour or soy flour supplemented with $0.3 \%$ methionine significantly lowered both serum cholesterol and glucose levels [18].

\section{Proteins from Oil-Producing Plants}

Oil-producing plants including soybeans, canola (rapeseed), sunflowers, safflowers, peanuts, corn, cottonseed, sesame, flax, and hemp are all potential sources of protein for human consumption. Oilproducing plants contain many proteins that have been isolated and proven suitable for human consumption [19].

\section{Seaweed Proteins}

Marine plants, especially brown, green, and red seaweed are mainly used for the production of phycocolloids or food. The protein content differs 
according to the species with, comparatively low protein content for brown seaweeds ( $3 \pm 15 \%$ of dry weight), a moderate amount for green algae $(9 \pm 26 \%$ of dry weight), and high amounts for red seaweeds (maximum $47 \%$ of dry weight). Important proteins and derived peptides like phycobiliproteins, glycoproteins, phycolectins, and mycosporine-like amino acids are present in seaweed along with polysaccharides and minerals. These compounds have been shown to exert prebiotic effects, regulate intestinal epithelial cells, aid in macrophage and lymphocyte proliferation and differentiation, and modulate the immune response [20]. The recent surge of interest in seaweed is fueled by attention to its bioactive components, which have potential applications in the lucrative functional food and nutraceutical industries. These applications are targeted toward the alleviation of metabolic risk factors such as hyperglycemia, hypercholesterolemia, and hyperlipidemia [21].

\section{Animal Proteins \\ Meat Proteins}

Meat protein sources include red meat, poultry, and fish. These sources provide all 20 amino acids which are present in approximately $20 \%$ of the total muscle weight and $80 \%$ of the dry mass in lean tissue. Based on their solubility, the meat proteins are divided into sarcoplasmic (e.g., myoglobin), myofibrillar (e.g., myosin and actin), and stromal proteins (e.g., collagen and elastin). Enzymes are bioactive proteins, whereas proteases are a special group of enzymes that are involved in protein turnover during muscle growth and development. Calpain, cathepsins, proteasomes, and aspases are important enzymes for meat tenderization. Additionally, some proteins used as technological ingredients in food processing (e.g., collagen, gelatin, and beef plasma protein) are mainly derived from muscle and animal tissues [22].

\section{Milk Proteins}

Milk is a complex biological fluid that provides nutrients and immunity to newborns. It provides essential amino acids along with minerals and lipids used for the development and function of muscles [23]. The active proteins in milk provide antibodies, metal and vitamin-binding proteins, and several protein hormones [24]. Cow milk is composed of $3.5 \%$ protein and these proteins are divided into two major groups called caseins ( $80 \%$ ) and whey proteins (20\%). Casein exists in milk as phosphoproteins in large colloidal aggregates including $\alpha s 1-$, and, $\alpha$ s-, as well as $\beta$ - and $k$-caseins known as casein micelles. Similarly, whey proteins are composed of $\beta$-lactoglobulin, $\alpha$ lactalbumin, serum albumin, immunoglobulins, lactoferrin, and protease-peptone fractions. $\mathrm{k}$-Casein only contains about $5 \%$ of carbohydrates (tri- or tetrasaccharides), $\mathrm{N}$-acetylneuraminic acid (sialic acid), galactose and $\mathrm{N}$-acetylgalactosamine [25]. Milk proteins are consumed in liquid form or as dried food supplements that are widely available on the market [26]. In newborns, the milk proteins coagulate very rapidly and form a large complex with calcium phosphate [27]. From its different biological and physicochemical properties, the heterogeneity and complexity of milk proteins were determined. These properties show that milk acts as a bioactive functional ingredient to regulate food intake and metabolism [28].

\section{Egg Proteins}

Eggs are high-quality protein resource that are also considered a functional food. Along with their high nutritional value and organoleptic characters, they provide lipids, valuable minerals, carbohydrates, and vitamins. Proteins comprise about $13 \%$ of egg contents and are morphologically divided into the white (albumen) and the yolk. Egg whites have excellent foaming properties and the yolks have emulsifying properties [29]. Egg white proteins contain $15 \%$ ovalbumin, $12-13 \%$ of ovotransferrin (conalbumin), and $11 \%$ ovomucoid, while the remaining $12-13 \%$ are minor proteins like lysozyme, G2- and G3-globulins, ovoinhibitor, cystatin, avidin and others. Once the egg yolk is separated by centrifugation it contains fractions of $\alpha$ - and $\beta$ lipoproteins (70\%), phosvitin (16\%), and low-density lipoprotein (LDL) (12\%) as well as some minor proteins, lipovitellin, phosvitin, and vitellogenin. The plasma from the yolk contains LDL, yolk riboflavinbinding protein, livetins, and biotin-binding protein [30]. Although the egg white protein is considered a source of high-quality protein, it contains ovoinhibitor, which is a serine proteinase inhibitor that inhibits digestive enzymes like trypsin, chymotrypsin, and elastase. This is considered an important factor which influences the $\mathrm{Gl}$ tract regulation, especially when consuming raw egg without thermal processing [31].

\section{The number of proteins received from animal and plant sources:}

To ensure the quality and quantity of proteins received from consuming dietary fiber in an ideal human diet, both plant and animal food source should be taken in suitable proportions. In human diets, plant-based diet provides $\sim 65 \%$ of proteins and animal-based diet provides $\sim 35 \%$ of proteins. A sufficient amount of amino acids can be obtained 
through the consumption of proper combinations of both legumes and cereals, but the availability of legumes has become limited globally [32]. Although this combination provides the protein requirements for most adults it is applicable to children. In elderly subjects, the deficiency of at least one essential amino acid was identified for those who consumed less than $65 \%$ of their total protein from animalsource foods [33]. The amount of proteins present in various plants and animal sources are depicted in Table 1.

Table 1. The amount of proteins present in various plant and animal sources.

\begin{tabular}{|c|c|c|c|c|c|c|}
\hline S. no & Plant Source & & $\begin{array}{l}\text { Value per } 100 \\
\text { grams }\end{array}$ & Animal Source & & $\begin{array}{l}\text { Value per } \\
100 \text { grams }\end{array}$ \\
\hline \multirow[t]{7}{*}{1} & Cereal & Barley & 9.91 & $\begin{array}{l}\text { Muscle } \\
\text { Proteins }\end{array}$ & Beef & 23.20 \\
\hline & & Maize & 9.42 & & Chicken & 21 \\
\hline & & Millet & 11.02 & & Fish & 21 \\
\hline & & Rice & 6.61 & & Lamb & 21.9 \\
\hline & & Sorghum & 11.30 & & Mutton & 21.5 \\
\hline & & Wheat bread & 10.69 & & Veal & 24.8 \\
\hline & & Wheat & 13.68 & & & \\
\hline \multirow[t]{13}{*}{2} & Pulse & Adzuki beans & 19.87 & $\begin{array}{l}\text { Egg proteins/1 } \\
\text { large }\end{array}$ & & 6 \\
\hline & & Black beans & 23.58 & $\begin{array}{l}\text { Milk } \\
\text { proteins/cup }\end{array}$ & & 8 \\
\hline & & Black gram & 25.21 & & & \\
\hline & & Chickpea & 19.30 & & & \\
\hline & & Cowpeas & 23.52 & & & \\
\hline & & Faba beans & 26.12 & & & \\
\hline & & Kidney beans & 21.60 & & & \\
\hline & & Lentils & 25.80 & & & \\
\hline & & Lima beans & 20.62 & & & \\
\hline & & Mung beans & 23.86 & & & \\
\hline & & Pigeon pea & 21.70 & & & \\
\hline & & Pinto beans & 19.87 & & & \\
\hline & & Soybeans & 16.6 & & & \\
\hline
\end{tabular}

\section{HUMAN GI MICROBIOTA}

The GI microbiota is an ecological community of symbiotic and pathogenic microorganisms that share our body space [34]. It is estimated that $\sim 1014$ bacterial cells are present in the human microbiome, a number 10 times more than the total number of human cells [35]. In the human gut, there are about 300-500 different bacterial species [36] with the most common phyla being Bacteroidetes (contains genera Bacteroides and Prevotella) and Firmicutes (contains genera Clostridium, Ruminococcus, and Eubacterium) which comprise more than $90 \%$ of the microbiota [37]. Some phyla like Actinobacteria, Spirochaetes, Proteobacteria, Verrucomicrobia, Lentisphaerae, and Fusobacteria are also present in lower proportions [38]. The fungal community present in the microbiota is known as the mycobiome, which comprises only
$0.001-0.1 \%$ of the microbial community and plays an important role in metabolic function, immunepriming, and maintaining the microbial community structure $[39,40]$. The gut virome is the viral component of the gut microbiota, mainly the eukaryotic viruses that can replicate in human cells and the bacteriophages that replicate in gut bacteria. Myoviridae, Podoviridae, Siphoviridae, and Microviridae are the important gut phages in the microbiota [41]. The development of the microbiota begins immediately at birth when the Gl tract is rapidly colonized. Life events such as illness, antibiotic treatment, or changes in diet, $\mathrm{pH}$, and bile flow can cause chaotic shifts in the microbiota [42].

The gut microbes found in the caecum and colon play a crucial role in the digestion of food for the host by helping to digest foods that cannot be broken 
down by stomach and intestine enzymes. Additionally, they play an important role in the host immune defenses along the intestine, including a mucus barrier, help prevent potentially harmful bacteria from causing damage to tissues. Furthermore, the microbiota assists in the production of vitamins $B$ and K. A healthy and balanced diet has been shown to maintain a stable and healthy gut microbiota and reduce the risk of various diseases [43]. The ingested foods are mainly digested in the stomach and small intestine but the indigestible food components and endogenous proteins secreted in the small intestine move towards the large intestine were fermentation and putrefaction take place with the help of microbes [44]. Therefore, gut microbes are recognized as a fundamental organ and an important factor in human physiology and nutrition $[45,46]$. Gut microbes also enhance metabolic capabilities and protect their host against pathogens $[46,47]$. The metabolic actions of microbiota are ultimately modulated by dietary proteins from plant and animal sources. This has been proven in many studies that observed protein sources and amounts as well as the way they affect the intestinal microbial balance [48].

\section{The beneficial effect of gut microbiota on host}

The gut bacteria do not only benefit the host by acting as a defense system, but also help to maintain the normal functions in the gut. Gut bacteria benefit the host by producing vitamins, metabolizing xenobiotic substances, regulating gut motility, transforming bile acid and steroids, activating, and absorbing minerals, and destroying toxins such as genotoxins and mutagens [42, 49]. High quantities of short-chain fatty acids (SCFA), such as acetic, butyric, and propionic acids in the proportion of 1:1:3 is produced in the proximal region of the colon. These SCFA act as energy sources for colonic mucosa, peripheral body tissues, and also for the metabolites of undigested complex carbohydrates. Collectively, these activities lead to the conservation of "lost" energy from the small intestine [50]. Bacteria like Lactobacillus, Bifidobacterium, and Bacteroides contribute to the synthesis of secondary bile acids, which are important components of lipid transport and turnover [51]. Vitamin B12 is synthesized by lactic acid bacteria, which cannot be synthesized by animals, plants, or fungi [52, 53]. Bifidobacterium also synthesizes important vitamins like $\mathrm{K}, \mathrm{B} 12$, biotin, folate, and thiamine which are helpful for major metabolic process including DNA synthesis and repair [54]. Furthermore, gut microbiota have been shown to synthesize riboflavin, pantothenic acid, pyridoxine, and thiamine [55]. Numerous lipids with biological activity are produced by bacteria, including lipopolysaccharide (LPS), a component in the cell wall of gram-negative bacteria that can cause tissue inflammation [56]. Many enzymes produced by microbe's influence digestion and health. Bacteroides thetaiotamicron especially produces many enzymes that are helpful for the breakdown of complex carbohydrate [57]. Likewise, bacterial phytases facilitate the degradation of phytic acid present in grains in order to release minerals such as calcium, magnesium, and phosphate [58].

\section{Gut bacteria and diseases}

The interaction between bacteria and human cells is also important for the maintenance of human health [59]. The gut bacteria live in a commensal manner within the human body, but if the microbiome undergoes abnormal changes, the gut bacteria may potentially become harmful. Hence, many diseases in humans and animal models can be used by dysbiosis [60]. For example, Clostridium difficile can cause pseudomembranous colitis due to antibiotic treatments administered after surgery. Similarly, Enterococcus faecalis, Escherichia coli, Enterococcus faecium, and Bacteroides fragilis can cause intraabdominal abscesses [61]. Due to these imbalances in gut bacteria, the intestine often produces symptoms like bloating, diarrhea, and abdominal pain. A large number of Bifidobacteria have a negative correlation with abdominal pain and the reduced number of Streptococcus, particularly S. alactolyticus, leads to diarrhea $[62,63]$. They also play an important role in appetite control, immune function, behavioral perturbations, energy balance, and allergies [62]. Additionally, there are many other diseases related to gut bacteria such as inflammatory bowel diseases [43], obesity [64, 65], heart diseases [23], cancers [66, 67], and diabetes [68]. Therefore, although the exact mechanisms are unknown, an understanding of the human microbiota can be applied to a wide range of health effects in human development, nutrition, immunity, and physiology [69].

\section{Effect of proteins on gut microbiota}

The effect of dietary protein on gut bacteria was first described by Hentges et al. [70]. In a culture-based study, they found that, subjects consuming a meatless diet, had decreased counts of Bifidobacterium adolescents as compared to subjects that consumed high beef diets and had increased counts of Bacteroides and Clostridia [70]. However, upon the consumption of animal protein, the counts of bile tolerant anaerobes such as Bacteroides, Alistipes, and Bilophila were increased [71]. This study supported former research in which the Italian and rural African village children's microbiotas were compared by the researchers. It was found that in Italian children, there was a large increase of 
Bacteroides and Alistipes in their microbiota upon the consumption of animal protein [72].

In most studies, protein consumption is positively associated with overall microbial diversity [73]. For example, the intake of a pea protein extract was previously reported to increase the microbes in the gut like Bifidobacterium and Lactobacillus and decrease pathogenic microbes like Bacteroides fragilis and Clostridium perfringens [74]. Additionally, the intestinal levels of SCFA, which act as antiinflammatory agents and maintain the mucosal barrier, were increased by pea protein [75]. To perform bioactivity, the transformation of natural compounds like lignans by gut bacteria is essential. These natural lignans are present in a variety of foods like vegetables, fruits, and flaxseed. The metabolization of lignans in flaxseed to enterolactone and enterodiol by gut microbiota can protect against diseases like cardiovascular disease, breast cancer, prostate cancer, colon cancer, hyperlipidemia, osteoporosis and menopausal syndrome [76]. Gut bacteria are necessary for the production and bioavailability of these enterolignans. The two gut bacteria, Peptostreptococcus SECO-Mt75m3 and Eggerthella lenta SECO-Mt75m2 allow demethylation and dehydroxylation of secoisolariciresinol which is one of the most abundant dietary lignans [77].

According to several studies, the consumption of soy foods positively alters the composition of the gut microbiota population. Soy and soy foods provide nutrients and energy that support the growth of certain gut microbiota [78]. Increased consumption of soy milk by people in Asia and the United States is a good example of the plant-based protein diet [79]. The many valuable nutrients in soy milk are used by gut microbiota and cause shifts in bacterial numbers
[80]. The effect of soy milk consumption on the gut microbiota was previously examined by FernandezRaudales and his colleagues. They primarily found that there was an increased amount of total gut bacterium in overweight and obese men. Additionally, the intake of soy milk changed the composition of bacteria by increasing the abundance of Bacteroidetes and Proteobacteria and reducing the populations and reducing the populations of Bifidobacteria and Firmicutes [81]. This shift causing an increase in Bacteroidetes and a decrease in Firmicutes ratio suggested that soy milk consumption reduces the risk of obesity and other metabolic syndromes [82]. Other evidence showed that soy protein from plants can bind to phytoestrogen compounds and induce lipid metabolism which lowers total cholesterol, low-density lipoprotein cholesterol, and triglyceride and also reduces insulin resistance, resulting in a better blood profile [83].

The proteins of algal extracts enhance growth and gut health by altering the gut microbiota population and increasing the digestibility and absorption of nutrients. Moreover, protein from seaweed alters the gut microbiota and modulates immune response, strengthening the gut barrier function [84]. Hutchins et al. [85] reported that the proteins in flaxseed diets significantly reduced the serum concentrations of $17 \beta$-oestradiol and oestrone sulfate and increased prolactin. Compared to plantbased diets, animal-based diets are high in fat which also affects the composition of microbes. Consequently, the mortality rate is lower in individuals that consume plant-derived proteins than in those who consume primarily animal-derived proteins (Fig. 1) [86]. Various studies on the effects of dietary proteins on diseases are depicted in Table 2.

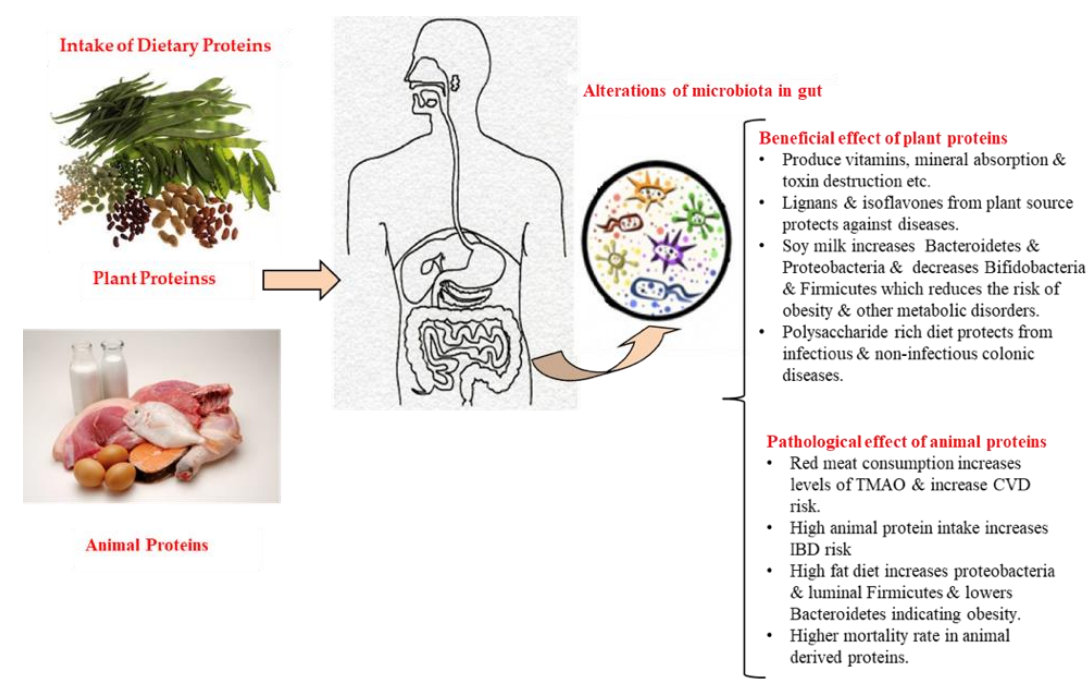

Figure 1. Beneficial and pathological effects of plant and animal proteins 
Table 2. The different studies on the effects of dietary proteins on diseases

\begin{tabular}{|c|c|c|c|c|c|}
\hline SI.no & $\begin{array}{l}\text { Dietary Component } \\
\text { Intake }\end{array}$ & Study Model & Duration & Main Finding & $\begin{array}{l}\text { Study } \\
\text { Cohort } \\
\text { (References) }\end{array}$ \\
\hline 1. & Soy food & $\begin{array}{l}20 \text { untreated patients } \\
\text { with chronic } \\
\text { glomerular diseases }\end{array}$ & 8 weeks & $\begin{array}{l}\text { Vegetarian soy diet could } \\
\text { correct the } \\
\text { hypercholesterolemia in } \\
\text { chronic glomerular disease } \\
\text { patients. }\end{array}$ & [87] \\
\hline 2. & Soy food & $\begin{array}{l}10 \text { cohort studies, } \\
12,888 \text { cases among } \\
452,916 \text { participants }\end{array}$ & 10 years & $\begin{array}{l}\text { Decreased the risk of breast } \\
\text { cancer. }\end{array}$ & {$[88]$} \\
\hline 3. & Plant protein & $\begin{array}{l}\text { A cohort study of } \\
70,696 \text { Japanese } \\
\text { adults aged } 45 \text { to } 74 \\
\text { years }\end{array}$ & 18 years & $\begin{array}{l}\text { A high intake of plant protein } \\
\text { was related to lower total } \\
\text { mortality. Reduces the risk of } \\
\text { cancer and cardiovascular } \\
\text { disease-related mortality. }\end{array}$ & [89] \\
\hline 4. & $\begin{array}{l}\text { Animal protein (Red } \\
\text { meat) }\end{array}$ & $\begin{array}{l}37,698 \text { men from the } \\
\text { Health Professionals } \\
\text { Follow-up Study and } \\
83,644 \text { women from } \\
\text { the Nurses' Health } \\
\text { Study who were free } \\
\text { of cardiovascular } \\
\text { disease (CVD) and } \\
\text { cancer }\end{array}$ & $\begin{array}{l}\text { Up to } 22 \\
\text { years for men } \\
\text { and } 28 \text { years } \\
\text { for women }\end{array}$ & $\begin{array}{l}\text { Red meat consumption is } \\
\text { associated with an increased } \\
\text { risk of CVD, } \\
\text { and cancer mortality. }\end{array}$ & [90] \\
\hline 5. & $\begin{array}{l}\text { Unprocessed red and } \\
\text { processed meats }\end{array}$ & $\begin{array}{l}100 \mathrm{~g} / \text { day }-9 \text { cohort } \\
\text { studies, } 447,333 \\
\text { individuals and } \\
28,206 \text { events. } \\
50 \mathrm{~g} / \text { day }-8 \text { cohort } \\
\text { studies, } 372,391 \\
\text { participants and } \\
26,234 \text { events }\end{array}$ & & $\begin{array}{l}\text { Unprocessed red and } \\
\text { processed meats increased } \\
\text { the risk of type } 2 \text { diabetes. }\end{array}$ & [91] \\
\hline 6. & $\begin{array}{l}\text { Fresh red meat and } \\
\text { processed meats }\end{array}$ & $\begin{array}{l}8 \text { cohort studies, } \\
19,912 \text { cases among } \\
691,383 \text { participants }\end{array}$ & & $\begin{array}{l}\text { Increased risk of breast } \\
\text { cancer. }\end{array}$ & [88] \\
\hline 7. & Animal protein & $\begin{array}{l}\text { NHANES study, 6,381 } \\
\text { adults }\end{array}$ & 18 years & $\begin{array}{l}\text { Increased death rate by } 75 \% \\
\text { and cancer death rate by } \\
400 \%\end{array}$ & [92] \\
\hline 8. & Animal protein & $\begin{array}{l}6,381 \text { participants } \\
\text { aged } 50-65 \text { years }\end{array}$ & & $\begin{array}{l}\text { High protein intake displayed } \\
\text { an increased in IGF-I levels, a } \\
75 \% \text { increase in overall } \\
\text { mortality and a 4-fold } \\
\text { increase in cancer and } \\
\text { diabetes. }\end{array}$ & [93] \\
\hline 9. & Animal protein & $\begin{array}{l}\text { 2,641 Finnish men, } \\
\text { aged } 42-60 \text { years }\end{array}$ & 5 years & $\begin{array}{l}\text { A higher ration of an animal } \\
\text { to plant protein diet and } \\
\text { higher meat intake were } \\
\text { associated with increased } \\
\text { mortality risk. }\end{array}$ & [94] \\
\hline 10. & $\begin{array}{l}\text { Animal and plant } \\
\text { protein }\end{array}$ & $\begin{array}{l}\text { Nurses health study } \\
85,013 \text { women and } \\
46,329 \text { men and } \\
\text { health professionals } \\
\text { Follow-up study }\end{array}$ & 32 years & $\begin{array}{l}\text { Animal protein intake was } \\
\text { positive with mortality } \\
\text { whereas plant protein was } \\
\text { inversely. }\end{array}$ & [95] \\
\hline 11. & $\begin{array}{l}\text { Plant and animal } \\
\text { proteins }\end{array}$ & $\begin{array}{l}\text { Adventist health } \\
\text { study } 281,337 \text { men } \\
\text { and women }\end{array}$ & 5 years & $\begin{array}{l}\text { Plant proteins showed less } \\
\text { cardiovascular mortality } \\
\text { whereas animal proteins } \\
\text { showed a high mortality rate. }\end{array}$ & [96] \\
\hline
\end{tabular}




\begin{tabular}{|c|c|c|c|c|c|}
\hline 12. & $\begin{array}{l}\text { Plant and animal } \\
\text { proteins }\end{array}$ & $\begin{array}{l}\text { Kuopio ischaemic } \\
\text { heart disease risk } \\
\text { factor study, } 2441 \\
\text { men, aged } 42 \text { to } 60 \\
\text { years }\end{array}$ & 5 years & $\begin{array}{l}\text { In middle-aged men, higher } \\
\text { protein intake was marginally } \\
\text { associated with increased risk } \\
\text { of heart failure. }\end{array}$ & [97] \\
\hline 13. & Animal protein & $\begin{array}{l}\text { Health professional's } \\
\text { follow-up study, } \\
40,475\end{array}$ & 20 years & $\begin{array}{l}\text { A low-carbohydrate diet high } \\
\text { in animal protein and fat was } \\
\text { positively associated with the } \\
\text { risk of type } 2 \text { diabetes. }\end{array}$ & [98] \\
\hline 14. & Animal protein & $\begin{array}{l}36 \text { studies, } 1803 \\
\text { participants, } 22 \text { to } 70 \\
\text { years }\end{array}$ & 2 to 36 weeks & $\begin{array}{l}\text { Substituting red meat with } \\
\text { high-quality plant protein } \\
\text { sources leads to more } \\
\text { favorable changes in blood } \\
\text { lipids and lipoproteins. }\end{array}$ & [5] \\
\hline 15. & Animal protein & $\begin{array}{l}43,396 \text { Swedish } \\
\text { women, aged 30-49 } \\
\text { years }\end{array}$ & 15.7 years & $\begin{array}{l}\text { Low carbohydrate-high } \\
\text { protein diets used regularly } \\
\text { are associated with increased } \\
\text { risk of cardiovascular disease. }\end{array}$ & [99] \\
\hline 16. & $\begin{array}{l}\text { Animal proteins and } \\
\text { plant proteins }\end{array}$ & $\begin{array}{l}112 \text { randomized } \\
\text { controlled trials }\end{array}$ & 3 weeks & $\begin{array}{l}\text { Plant protein in substitution } \\
\text { of animal protein decreased } \\
\text { low-density lipoprotein } \\
\text { cholesterol. }\end{array}$ & [100] \\
\hline 17. & $\begin{array}{l}\text { Animal protein and } \\
\text { plant protein }\end{array}$ & $\begin{array}{l}\text { A meta-analysis of } \\
\text { randomized } \\
\text { controlled trials }\end{array}$ & 3 weeks & $\begin{array}{l}\text { Replacing animal protein with } \\
\text { plant protein control glycemic } \\
\text { level in diabetes. }\end{array}$ & [101] \\
\hline 18. & Animal protein & $\begin{array}{l}196 \text { patients, } 177 \\
\text { who complied with } \\
\text { the dietary advice } \\
\end{array}$ & $2-7$ years & $\begin{array}{l}\text { Animal protein as the main } \\
\text { cause of heart disease. }\end{array}$ & [102] \\
\hline 19. & Plant protein & $\begin{array}{l}\text { Among } 1380 \text { adults, } \\
30 \text { to } 54 \text { years of ages }\end{array}$ & 12 years & $\begin{array}{l}\text { Plant protein maintains } \\
\text { muscle mass and function } \\
\text { better than animal protein. }\end{array}$ & [103] \\
\hline 20. & Plant protein & $\begin{array}{l}\text { Framingham third- } \\
\text { generation study, } \\
2986 \text { men and } \\
\text { women, aged } 19-72 \\
\text { years }\end{array}$ & 3 years & $\begin{array}{l}\text { Consuming plant protein food } \\
\text { can build muscles. }\end{array}$ & [104] \\
\hline 21. & $\begin{array}{l}\text { Animal protein (Red } \\
\text { meat) }\end{array}$ & $\begin{array}{l}37,035 \text { men, aged } 45 \\
\text { to } 79 \text { years with no } \\
\text { history of Heart } \\
\text { Failure, ischemic } \\
\text { heart disease, } \\
\text { or cancer }\end{array}$ & 11.8 years & $\begin{array}{l}\text { Processed red meat } \\
\text { consumption, but not } \\
\text { unprocessed red meat, is } \\
\text { associated with an increased } \\
\text { risk of heart failure. }\end{array}$ & [6] \\
\hline 22. & Plant Protein (Soy) & $\begin{array}{l}59 \text { postmenopausal } \\
\text { women, aged } 44-65 \\
\text { years) }\end{array}$ & 12 weeks & $\begin{array}{l}\text { Greater improvement was } \\
\text { observed in cardiovascular } \\
\text { disease risk factors in } \\
\text { postmenopausal women on } \\
\text { incorporating } 30 \mathrm{~g} \text { of soy } \\
\text { protein and } 4 \mathrm{~g} \text { of } \\
\text { phytosterols per day. }\end{array}$ & [105] \\
\hline 23. & Plant protein (Soy) & $\begin{array}{l}\text { Male Zucker Diabetic } \\
\text { Fatty (ZDF/Lepr(fa)) } \\
\text { rats }\end{array}$ & 11 weeks & $\begin{array}{l}\text { Soy protein with low or high } \\
\text { isoflavone content may have } \\
\text { therapeutic significance in } \\
\text { reducing the severity of } \\
\text { diabetes, and renal disease. }\end{array}$ & [106] \\
\hline 24. & Plant protein (Soy) & $\begin{array}{l}\text { Male Sprague-Dawley } \\
\text { rats ( } 4-16 \text { wk old) and } \\
\text { yellow KK mice (6-10 } \\
\text { wk old) were made } \\
\text { obese by feeding } \\
\text { high-fat diets } \\
\text { containing } 30 \% \text { fat }\end{array}$ & 4 weeks & $\begin{array}{l}\text { Soy protein isolate and its } \\
\text { hydrolysate are } \\
\text { suitable protein sources in } \\
\text { energy-restricted diets for the } \\
\text { treatment of obesity. }\end{array}$ & [107] \\
\hline
\end{tabular}




\begin{tabular}{|c|c|c|c|c|c|}
\hline 25. & Plant protein (Soy) & $\begin{array}{l}\text { Randomized } \\
\text { crossover trial in } 15 \\
\text { postmenopausal } \\
\text { women with } \\
\text { abdominal obesity }\end{array}$ & 4 weeks & $\begin{array}{l}\text { Partly replacing meat } \\
\text { products with soy products } \\
\text { could be important in } \\
\text { preventing Metabolic } \\
\text { Syndrome. }\end{array}$ & [108] \\
\hline 26. & Plant protein (Soy) & Obese Zucker rats & 160 days & $\begin{array}{l}\text { Renoprotection by Soy } \\
\text { protein. }\end{array}$ & [109] \\
\hline 27. & $\begin{array}{l}\text { Animal Protein (Dairy } \\
\text { \& meat) }\end{array}$ & $\begin{array}{l}52,062 \text { women aged } \\
35-50 \text { years }\end{array}$ & 12 years & $\begin{array}{l}\text { Breast cancer risk for African- } \\
\text { American women with dairy } \\
\text { and meat intake. }\end{array}$ & [110] \\
\hline 28. & $\begin{array}{l}\text { Animal Protein (Red } \\
\text { meat) }\end{array}$ & $\begin{array}{l}44,231 \text { women aged } \\
33-52 \text { years }\end{array}$ & 13 years & $\begin{array}{l}\text { Higher consumption of } \\
\text { red meat during adolescence } \\
\text { was associated with } \\
\text { premenopausal } \\
\text { breast cancer. }\end{array}$ & [111] \\
\hline
\end{tabular}

\section{DIETARY PROTEIN AND HUMAN HEALTH Dietary protein and cancer}

As shown in recent epidemiological studies, the consumption of large quantities of animal protein increases the risk of cancer and diabetes [90, 112]. Heme iron, heterocyclic amines, and endogenous $\mathrm{N}$ nitroso compounds initiate carcinogenesis by enabling lipid peroxidation of epithelial cells and facilitating DNA and cellular damage of the gastrointestinal tract, eventually lead to adenocarcinoma. Cross et al. [113] proved this in a cohort study that found a significant association between colorectal cancer and the intake of heme iron, nitrate from processed meat, and heterocyclic amines. Further, the study added that both red and processed meat intake was positively associated with colorectal cancer. Processed meat is also a predominant source of nitrite for human. In contrast to red meat, white meat is not associated with an elevated risk of colorectal cancer [113]. This has been confirmed recently by a large group of studies involving the Health Professional Follow-up Study, Nurse's Health Study, and the Multiethnic Cohort [114].

\section{Dietary protein, diabetes, and cardiovascular disease}

Grapes, cocoa, tea, grains, and berries are dietary polyphenols, which generally promote health and prevents diseases like cancer and cardiovascular diseases [115]. L-Carnitine from red meat produced by microbial metabolism forms the intermediate trimethylamine- $\mathrm{N}$-oxide (TMAO) that could potentially increase atherosclerosis risk [116, 117]. The by-product of choline, trimethylamine (TMA), is found in liver, eggs, red meat, milk, poultry and fish may increase the risk of stroke and heart disease. This has been proven through the lifestyle of Western people, who consume highly processed omnivorous diets of poor nutritional quality. These diets have dense energy, which is, high in animal protein, total and saturated fats, and simple sugars but low in fruits, vegetables, and other plant-based foods. Thereby, this Western lifestyle diet is related to a high occurrence of chronic diseases such as colorectal cancer, type II diabetes, and cardiovascular diseases [118].

\section{Dietary protein and obesity}

In the gut, a high-fat diet alters the composition of bacteria by facilitating high levels of Proteobacteria and luminal Firmicutes and lower levels of Bacteroidetes [119]. This change in the levels of certain gut bacteria indicates a decrease in diversity and a potential linkage to obesity. The ratio of Firmicutes to Bacteroides is correlated to body weight and in people who are obese, there is a higher ratio between the two bacteria [120]. Moreover, gut bacteria could also affect obesity by promoting chronic inflammatory status [121]. The infection of Clostridium difficile has also been proven to potentially cause obesity [122].

\section{Dietary protein and inflammatory bowel disease (IBD)}

Several mechanisms prove that diet could influence the occurrence of IBD, which includes a change in the gut microbiota, direct dietary antigens, and altered the permeability of the gastro intestine [123]. Additionally, dietary components have an important relationship with the risk of IBD development. The intake of sugar and refined carbohydrates is the first dietary component that leads to the development of IBD [124]. Diet fatty acids and protein compositions have a reliable association with the development of IBD that has been observed in cohort and ecological studies [125]. High-fat diets also cause increased bowel permeability, a hallmark of Chron's disease, through the diet-induced changes in gut bacteria [126]. The consumption of saturated fat from milk alters bile acid compositions and allows the extensive growth of sulfate-reducing bacteria by producing large amounts of hydrogen sulfide, which causes mucosal damage. Sulphur amino acid, found mainly in 
meats, is the major source of hydrogen sulfide in the bowel and is produced by bacterial fermentation [127]. Hydrogen sulfide contributes to bowel inflammation by impairing the utilization of direct toxic effects and short-chain fatty acids [128]. Thus, from many studies, it has been observed that diet is strongly associated with the development of IBD.
Additionally, Jowett et al. found that patients were more likely to have a relapse of ulcerative colitis when consuming more of eggs, red meat, and alcohol. Thus, red meat and processed meat have a stronger association with ulcerative colitis that is not seen with fish consumption [129]. The influence of diet on microbiota and host health is depicted in Table 3.

Table 3. Some examples of studies on the influence of diet on the microbiota and host health.

\begin{tabular}{|c|c|c|c|c|}
\hline SI. No & Diet & Effect on microbiota & Effect on host & References \\
\hline 1. & Pea nut & $\begin{array}{l}\text { Increased the Bifidobacterium } \\
\text { communities, and reduced } \\
\text { the Enterobacteria and } \\
\text { Clotridium perfringensa }\end{array}$ & $\begin{array}{l}\text { Inhibited the growth of } \\
\text { enterohemorrhagic Escherichia } \\
\text { coli, Listeria monocytogenes, and } \\
\text { Salmonella Typhimurium. }\end{array}$ & {$[130]$} \\
\hline 2. & Soybean & $\begin{array}{l}\text { Increased communities of } \\
\text { Escherichia and } \\
\text { Propionibacterium }\end{array}$ & $\begin{array}{l}\text { Escherichia and Shigella, modulate } \\
\text { salt and water metabolism } \\
\text { without impairment of intestinal } \\
\text { mucosa. }\end{array}$ & {$[131]$} \\
\hline 3. & Soy protein & $\begin{array}{l}\text { Elevated levels of } \\
\text { Bifidobacteriaceae and } \\
\text { Clostridales spp. }\end{array}$ & $\begin{array}{l}\text { Reduced total cholesterol, TG and } \\
\text { VLDL levels. Higher expression of } \\
\text { 3- hydroxy-3-methylglutaryl-CoA } \\
\text { reductase (Hmgcr), lanosterol } \\
\text { synthase (Lss), and farnesyl- } \\
\text { diphosphosphate } \\
\text { farnesyltransferase } 1 \text { (Fdft1), and } \\
\text { lower steroyl-CoA desaturase-1 } \\
\text { (Scd1) expression. }\end{array}$ & [78] \\
\hline
\end{tabular}

\begin{tabular}{|c|c|c|c|c|}
\hline 4. & Seaweed & $\begin{array}{l}\text { Increase the beneficial } \\
\text { bacteria such } \\
\text { as Lactobacillus spp. } \\
\text { and Bifidobacterium and } \\
\text { decreased the potentially } \\
\text { pathogenic bacteria such } \\
\text { as Enterobacteria }\end{array}$ & $\begin{array}{l}\text { Altering gut microbiota and/or } \\
\text { modulating immune function and } \\
\text { thus strengthening the gut barrier } \\
\text { function. }\end{array}$ & [84] \\
\hline 5. & High beef diet & $\begin{array}{l}\text { The decrease in } \\
\text { Bifidobacterium adolescents } \\
\text { and increase in Bacteroides } \\
\text { and Clostridia }\end{array}$ & $\begin{array}{l}\text { Increases Trimethylamine N-oxide } \\
\text { and decreases Short-chain fatty } \\
\text { acids leads to Cardio-vascular \& } \\
\text { Inflammatory Bowel Diseases. }\end{array}$ & [70] \\
\hline 6. & $\begin{array}{l}\text { Whey \& Pea } \\
\text { protein extract }\end{array}$ & $\begin{array}{l}\text { Increase in Bifidobacterium \& } \\
\text { Lactobacillus and Decrease in } \\
\text { Bacteroides fragilis \& } \\
\text { Clostridium perfringens }\end{array}$ & $\begin{array}{l}\text { Increases Short-chain fatty acids } \\
\text { which lead to an increase in the } \\
\text { gut barrier, T-regulatory cells \& } \\
\text { decreases inflammation. }\end{array}$ & [74] \\
\hline 7. & $\begin{array}{l}\text { Animal-based } \\
\text { diet }\end{array}$ & $\begin{array}{l}\text { The increase of bile tolerant } \\
\text { anaerobes such as } \\
\text { Bacteroides, Alistipes and } \\
\text { Bilophila }\end{array}$ & $\begin{array}{l}\text { Increases Trimethylamine N-oxide } \\
\text { and leads to Cardio-vascular \& } \\
\text { Inflammatory Bowel Diseases. }\end{array}$ & [132] \\
\hline 8. & Soy milk & $\begin{array}{l}\text { Increases Bacteroidetes and } \\
\text { Proteobacteria and Decreases } \\
\text { Bifidobacteria and Firmicutes }\end{array}$ & $\begin{array}{l}\text { Reduces the risk of Obesity and } \\
\text { other Metabolic syndromes. }\end{array}$ & {$[82]$} \\
\hline 9. & $\begin{array}{l}\text { Low fruit, } \\
\text { vegetables, } \\
\text { and fish }\end{array}$ & $\begin{array}{l}\text { Reduces microbial gene } \\
\text { richness }\end{array}$ & $\begin{array}{l}\text { Increases insulin resistance, } \\
\text { fasting serum triglyceride and LDL } \\
\text { cholesterol levels and } \\
\text { inflammation. }\end{array}$ & [71] \\
\hline
\end{tabular}

\section{DIETARY PROTEIN}

This review provides an overview of recent research detailing the importance of the of the interaction between dietary proteins and gut bacteria and human health and diseases. Many diseases like obesity, diabetes, IBD, and cancer, are impacted by the imbalance of gut bacteria mainly by affecting the immune-regulatory activity. Thus, these diseases are due to diet-induced dysbiosis. There are also many studies undergone related to the beneficial effect of diets to the gut microbiota in the host. For example, plant-based diets minimize cardiovascular disease 
risk. Through the discussion of various studies, this review describes how plant proteins, rather than animal proteins, are beneficial the plant protein acts beneficial to the gut bacterial microbiota and prevent many serious diseases in humans.

Acknowledgments: The work was jointly supported by two grants (R201627 and R201714) from Beijing Normal University-Hong Kong Baptist University United International College, Zhuhai, Guangdong, China.

Conflicts of Interest: The authors declare that there are no conflicts of interest.

A Statement of Ethical Background: The current article is a review paper and so there are no ethical issues are considered.

\section{REFERENCES}

1. Reynolds CM, Gray C, Li M, Segovia SA, Vickers MH: Early Life Nutrition and Energy Balance Disorders in Offspring in Later Life. Nutrients 2015, 7(9): 8090-8111.

2. Jahan-Mihan A, Luhovyy BL, El Khoury D, Anderson GH: Dietary proteins as determinants of metabolic and physiologic functions of the gastrointestinal tract. Nutrients 2011, 3(5): 574-603.

3. Pereira PM, Vicente AF: Meat nutritional composition and nutritive role in the human diet. Meat Sci 2013, 93(3): 586-592.

4. Hoffman JR, Falvo MJ: Protein - Which is Best? J Sports Sci Med 2004, 3(3):118-130

5. Guasch-Ferre $M$, Satija A, Blondin SA, Janiszewski $M$, Emlen E, O'Connor LE, Campbell WW, et al.: Metaanalysis of randomized controlled trials of red meat consumption in comparison with various comparison diets on cardiovascular risk factors. Circulation 2019, 139(15): 1828-1845.

6. Kaluza J, Akesson A, Wolk A: Processed and unprocessed red meat consumption and risk of heart failure: prospective study of men. Circ Heart Fail 2014, 7(4): 552557.

7. Bastide NM, Chenni F, Audebert M, Santarelli RL, Tache S, Naud N, Baradat $M$, et al.: A central role for heme iron in colon carcinogenesis associated with red meat intake. Cancer Res. 2015, 75(5): 870-879.

8. Lásztity R: The chemistry of cereal proteins. 2nd edition. FL. USA: Boca Raton; 1996.

9. Borneo $\mathrm{R}$, Leon $\mathrm{AE}$ : Whole grain cereals: functional components and health benefits. Food Funct 2012, 3(2): 110-119.

10. Murtaugh MA, Jacobs DR, Jr., Jacob B, Steffen LM, Marquart L: Epidemiological support for the protection of whole grains against diabetes. Proc Nutr Soc 2003, 62(1):143-149.

11. Boye JZ, Pletch A: Pulse proteins: Processing, characterization, functional properties and applications in food and feed. Food Res Int 2010, 43:414-431.

12. Mudryj AN, Yu N, Aukema HM: Nutritional and health benefits of pulses. Appl Physiol Nutr Metab 2014, 39(11): 1197-1204.

13. Dahl WJ, Foster LM, Tyler RT: Review of the health benefits of peas (Pisum sativum L.). Br J Nutr 2012, 108: s3-10.
14. Derbyshire E, Wright DJ, Boulter D: Review: Legumin and vicilin, storage proteins of legume seeds. Phytochem 1976, 15:3.

15. Liu KS: Chemistry and nutritional value of soybean components. In: Soybean: Chemistry, technology and utilization. New York: Chapman \& Hall; 1997: 25-113.

16. Gyöngyi Hajos EG, George Grant, Susan Bardocz, Mohamed Sakhri, Tracey J, Duguid, April M, et al.: Effect of proteolytic modification and methionine enrichment on the nutritional value of soya albumins for rats. J Nutr Biochem 1996, 7: 481-487.

17. Carroll KK, Kurowska EM: Soy consumption and cholesterol reduction: review of animal and human studies. J Nutr 1995, 125: 594S-597S.

18. Taha SA, Wasif MM: Hypoglycemic effect and protein nutritive quality of soy and methionine-supplemented whole durum pasta products. Nahrung 1996, 40(5): 281287.

19. Arntfield SD: Proteins from oil-producing plants. In Proteins in Food Processing. Edited by Yada RY. Cambridge, UK: Woodhead Publishing; 2004.

20. Fleurence J, Morancais M, Dumay J: From Seaweed proteins. Edited by Yada, RY. Cambridge, UK: Woodhead Publishing; 2004.

21. Collins KG, Fitzgerald GF, Stanton C, Ross RP. Looking beyond the terrestrial: The potential of seaweed derived bioactives to treat non-communicable diseases. Mar Drugs 2016, 14(3).

22. Xiong YL: Muscle Proteins. In Proteins in Food Processing. Edited by Yada RY. Cambridge, UK: Woodhead Publishing; 2004.

23. Haug A, Hostmark AT, Harstad OM: Bovine milk in human nutrition--a review. Lipids Health Dis 2007, 6: 25.

24. Fox PF, McSweeney PLH, O'Mahony JA: Heat-induced changes in milk: Dairy Chemistry and Biochemistry. Springer International Publishing; 2015.

25. Fox P, McSweeney P: Dairy Chemistry and Biochemistry. London, UK: Blackie Academic \& Professional; 1998.

26. Deeth H, Hartanto J: Chemistry of Milk-Role of constituents in evaporation and drying. In Dairy Powders and Concentrated Milk Products, Edited by Tamime, UK: Blackwell Publishing: Chichester; 2009: 1-27,

27. McKenzie, H: Milk Proteins VI: ed., Chemistry and molecular biology. Elsevier. 2012.

28. Anderson GH LB, Akhavan T, Panahi S: Milk proteins in the regulation of body weight, satiety, food intake and glycemia. Nestle Nutr Workshop Ser Pediatr Program 2011, 67: 147-159.

29. Phillips GO, Williams PA: Egg Proteins. In: Handbook of Food Proteins. Edited by Strixner T, Kulozik U. Oxford, USA: Woodhead Publishing Limited; 2011: 150-209.

30. Nakamura R, Doi, D: Egg Processing. In: Food Proteins: Processing Applications. Edited by Nakai S, Modler HW, New York, USA: Wiley-VCH; 2000: 171-207.

31. Begum S, Saito A, Kato A, He J, Azakami H: Expression and characterization of chicken ovoinhibitor in Pichia pastoris. Nahrung 2003, 47(5): 359-363.

32. Akibode S, Maredia M: Global and regional trends in production, trade and consumption of food legume crops. Michigan State University; 2011.

33. Dasgupta M, Sharkey JR, Wu G: Inadequate intakes of indispensable amino acids among homebound older adults. J Nutr Elder 2005, 24(3): 85-99.

34. Group NHW, Peterson J, Garges S, Giovanni M, Mclnnes $P$, Wang L, Schloss JA, et al.: The NIH Human Microbiome Project. Genome Res 2009, 19(12): 2317-2323.

35. Hattori M, Taylor TD: The human intestinal microbiome: a new frontier of human biology. DNA Res 2009, 16(1): 112.

36. O'Hara AM, Shanahan F: The gut flora as a forgotten organ. EMBO Rep 2006, 7(7): 688-693. 
37. Frank DN, St Amand AL, Feldman RA, Boedeker EC, Harpaz N, Pace NR: Molecular-phylogenetic characterization of microbial community imbalances in human inflammatory bowel diseases. Proc Natl Acad Sci U S A 2007, 104(34):13780-13785.

38. Sekirov I, Russell SL, Antunes LC, Finlay BB: Gut microbiota in health and disease. Physiol Rev 2010, 90(3): 859-904.

39. Auchtung TA, Fofanova TY, Stewart CJ, Nash AK, Wong $\mathrm{MC}$, Gesell JR, Auchtung JM, et al.: Investigating colonization of the healthy adult gastrointestinal tract by fungi. mSphere 2018, 3(2)

40. Seed PC: The human mycobiome. Cold Spring Harb Perspect Med 2014, 5(5): a019810.

41. Zarate S, Taboada B, Yocupicio-Monroy M, Arias CF: Human Virome. Arch Med Res 2017, 48(8): 701-716.

42. Thursby $\mathrm{E}$, Juge $\mathrm{N}$ : Introduction to the human gut microbiota. Biochem J 2017, 474(11): 1823-1836

43. Conlon MA, Bird AR: The impact of diet and lifestyle on gut microbiota and human health. Nutrients 2014 7(1):17-44

44. Hervert-Hernández D GI: Dietary polyphenols and human gut microbiota: a review. Food Rev Int 2011, 27:154-169.

45. Davila $A M$, Blachier $F$, Gotteland $M$, Andriamihaja $M$, Benetti PH, Sanz Y, Tome D: Intestinal luminal nitrogen metabolism: role of the gut microbiota and consequences for the host. Pharmacol Res. 2013, 68(1): 95-107.

46. Round JL, Mazmanian SK: The gut microbiota shapes intestinal immune responses during health and disease. Nat Rev Immunol 2009, 9(5): 313-323.

47. Celli J, Deng W, Finlay BB: Enteropathogenic Escherichia coli (EPEC) attachment to epithelial cells: exploiting the host cell cytoskeleton from the outside. Cell Microbiol 2000, 2(1): 1-9.

48. Muhammad Shahid, Riaz Rajoka JS, Hafiza Mahreen Mehwish, Jing Zhu, Qi Li, Dongyan Shao, Qingsheng Huang, Hui Yang: Interaction between diet composition and gut microbiota and its impact on gastrointestinal tract health. Food Sci Hum Wellness 2017, 6: 121-130.

49. Natividad JM, Verdu EF: Modulation of intestinal barrier by intestinal microbiota: pathological and therapeutic implications. Pharmacol Res 2013, 69(1): 42-51.

50. Ramakrishna BS: Role of the gut microbiota in human nutrition and metabolism. J Gastroenterol Hepatol 2013, 28: 9-17.

51. Nicholson JK, Holmes E, Kinross J, Burcelin R, Gibson G, Jia W, Pettersson S: Host-gut microbiota metabolic interactions. Science 2012, 336(6086): 1262-1267.

52. LeBlanc JG, Milani C, de Giori GS, Sesma F, van Sinderen $D$, Ventura M: Bacteria as vitamin suppliers to their host: a gut microbiota perspective. Curr Opin Biotechnol 2013, 24(2): 160-168.

53. Martens JH, Barg H, Warren MJ, Jahn D: Microbial production of vitamin B12. Appl Microbiol Biotechnol 2002, 58(3):275-285.

54. Pompei A, Cordisco L, Amaretti A, Zanoni S, Matteuzzi D, Rossi $\mathrm{M}$ : Folate production by bifidobacteria as a potential probiotic property. Appl Environ Microbiol 2007, 73(1): 179-185.

55. Hill MJ: Intestinal flora and endogenous vitamin synthesis. Eur J Cancer Prev 1997, 6: S43-45.

56. Trent MS, Stead CM, Tran AX, Hankins JV: Diversity of endotoxin and its impact on pathogenesis. J Endotoxin Res 2006, 12(4): 205-223.

57. Xu J, Bjursell MK, Himrod J, Deng S, Carmichael LK, Chiang HC, Hooper LV, Gordon JI: A genomic view of the humanBacteroides thetaiotaomicron symbiosis. Science 2003, 299(5615): 2074-2076.
58. Sandberg AS AT: Phytogenic and microbial phytases in human nutrition. Int J Food Sci Technol 2002, 37:823-833.

59. Brestoff JR, Artis D: Commensal bacteria at the interface of host metabolism and the immune system. Nat Immunol 2013, 14(7): 676-684.

60. Hawrelak JA, Myers SP: The causes of intestinal dysbiosis: a review. Altern Med Rev 2004, 9(2): 180-197.

61. Wilcox $\mathrm{MH}$ : Gastrointestinal disorders and the critically ill. Clostridium difficile infection and pseudomembranous colitis. Best Pract Res Clin Gastroenterol 2003, 17(3): 475493.

62. Hermann-Bank ML, Skovgaard K, Stockmarr A, Larsen N, Molbak L: The Gut Microbiotassay: a high-throughput qPCR approach combinable with next generation sequencing to study gut microbial diversity. BMC Genomics 2013, 14:788.

63. Landete J: Plant and mammalian lignans: A review of source, intake, metabolism, intestinal bacteria and health. Food Res Int 2012, 46: 410-424.

64. Ley RE: Obesity and the human microbiome. Curr Opin Gastroenterol 2010, 26(1): 5-11.

65. Turnbaugh PJ, Hamady $\mathrm{M}$, Yatsunenko $\mathrm{T}$, Cantarel $\mathrm{BL}$, Duncan A, Ley RE, Sogin ML: A core gut microbiome in obese and lean twins. Nature 2009, 457(7228): 480-484.

66. Schwabe RF, Jobin C: The microbiome and cancer. Nat Rev Cancer 2013, 13(11): 800-812.

67. Zackular JP, Rogers MA, Ruffin MT, Schloss PD: The human gut microbiome as a screening tool for colorectal cancer. Cancer Prev Res (Phila) 2014, 7(11): 1112-1121.

68. Qin J LY, Cai Z, Li S, Zhu J, Zhang F, et al.: A metagenomewide association study of gut microbiota in type 2 diabetes. Nature 2012, 490: 55-60.

69. Dethlefsen L, McFall-Ngai M, Relman DA: An ecological and evolutionary perspective on human-microbe mutualism and disease. Nature 2007, 449(7164): 811-818.

70. Hentges DJ, Maier BR, Burton GC, Flynn MA, Tsutakawa RK: Effect of a high-beef diet on the fecal bacterial flora of humans. Cancer Res 1977, 37(2): 568-571.

71. Cotillard A, Kennedy SP, Kong LC, Prifti E, Pons N, Le Chatelier $\mathrm{E}$, Almeida $\mathrm{M}$, et al.: Dietary intervention impact on gut microbial gene richness. Nature 2013, 500(7464): 585-588.

72. Jantchou P, Morois S, Clavel-Chapelon F, Boutron-Ruault MC, Carbonnel F: Animal protein intake and risk of inflammatory bowel disease: The $\mathrm{E} 3 \mathrm{~N}$ prospective study. Am J Gastroenterol 2010, 105(10): 2195-2201.

73. Clarke SF, Murphy EF, O'Sullivan O, Lucey AJ, Humphreys M, Hogan A, Hayes P, et al.: Exercise and associated dietary extremes impact on gut microbial diversity. Gut 2014, 63(12): 1913-1920.

74. Swiatecka D, Narbad A, Ridgway KP, Kostyra H: The study on the impact of glycated pea proteins on human intestinal bacteria. Int J Food Microbiol 2011, 145(1): 267-272.

75. Kim $\mathrm{CH}$, Park J, Kim M: Gut microbiota-derived shortchain Fatty acids, T cells, and inflammation. Immune Net w 2014, 14(6): 277-288.

76. Fuentealba C, Figuerola F, Estevez AM, Bastias JM, Munoz O: Bioaccessibility of lignans from flaxseed (Linumusita tissimum L.) determined by single-batch in vitro simulation of the digestive process. J Sci Food Agric 2014, 94(9): 1729-1738.

77. Clavel T, Henderson G, Alpert CA, Philippe C, RigottierGois L, Dore J, Blaut M: Intestinal bacterial communities that produce active estrogen-like compounds enterodiol and enterolactone in humans. Appl Environ Microbiol 2005, 71(10): 6077-6085.

78. Butteiger DN, Hibberd AA, McGraw NJ, Napawan N, HallPorter JM, Krul ES: Soy protein compared with milk protein in a western diet increases gut microbial diversity 
and reduces serum lipids in golden Syrian Hamsters. Nutr 2016, 146(4): 697-705.

79. Lawrence SE, Lopetcharat K, Drake MA: Preference mapping of Soymilk with different U.S. consumers. J Food Sci 2016, 81(2): S463-476.

80. Nakasato $\mathrm{KO}$, Ishiguro $\mathrm{T}$, Takamatsu $\mathrm{M}$, Tsukamoto $\mathrm{C}$ Mikami M: Rapid quantitative analysis of the major components in soymilk using Fourier-transform infrared spectroscopy (FT-IR). Food Sci Technol Res 2004, 10: 137142.

81. Fernandez-Raudales D, Hoeflinger JL, Bringe NA, Cox SB, Dowd SE, Miller MJ, Gonzalez de Mejia E: Consumption of different soymilk formulations differentially affects the gut microbiomes of overweight and obese men. Gut Microbes 2012, 3(6): 490-500.

82. Carmody RN, Gerber GK, Luevano JM, Gatti DM, Somes L, Svenson KL, Turnbaugh PJ: Diet dominates host genotype in shaping the murine gut microbiota. Cell Host Microbe 2015, 17(1): 72-84.

83. Cederroth CR, Nef S: Soy, phytoestrogens and metabolism: A review. Mol Cell Endocrinol. 2009, 304(12): $30-42$.

84. Overland M, Mydland LT, Skrede A: Marine macroalgae as sources of protein and bioactive compounds in feed for monogastric animals. J Sci Food Agric 2019, 99(1): 1324.

85. Hutchins AM, Martini MC, Olson BA, Thomas W, Slavin JL: Flaxseed influences urinary lignan excretion in a dosedependent manner in postmenopausal women. Cancer Epidemiol Biomarkers Prev 2000, 9(10): 1113-1118.

86. Levine ME, Suarez JA, Brandhorst $S$, Balasubramanian $P$, Cheng CW, Madia F, Fontana L, et al.: Low protein intake is associated with a major reduction in IGF-1, cancer, and overall mortality in the 65 and younger but not older population. Cell Metab 2014, 19(3): 407-417.

87. D'Amico G, Gentile MG, Manna G, Fellin G, Ciceri R Cofano $F$, Petrini $C$, et al.: Effect of vegetarian soy diet on hyperlipidaemia in nephrotic syndrome. Lancet 1992 , 339(8802): 1131-1134.

88. Wu J, Zeng R, Huang J, Li X, Zhang J, Ho JC, Zheng Y: Dietary protein sources and incidence of Breast Cancer: $A$ dose-response meta-analysis of prospective studies. Nutrients 2016, 8(11)

89. Budhathoki S, Sawada N, Iwasaki M, Yamaji T, Goto A Kotemori A, Ishihara J, et al.: Japan public health centerbased prospective study G. Association of animal and plant protein intake with all-cause and cause-specific mortality in a Japanese cohort. JAMA Intern Med 2019, 179(11): 1509-1518.

90. Pan A, Sun $Q$, Bernstein AM, Schulze MB, Manson JE, Stampfer MJ, Willett WC, Hu FB: Red meat consumption and mortality: results from 2 prospective cohort studies. Arch Intern Med 2012, 172(7): 555-563.

91. Micha R, Michas G, Mozaffarian D: Unprocessed red and processed meats and risk of coronary artery disease and type 2 diabetes- an updated review of the evidence. Curr Atheroscler Rep 2012, 14(6): 515-524.

92. Levine ME: Modeling the rate of senescence: can estimated biological age predict mortality more accurately than chronological age? J Gerontol A Biol Sci Med Sci 2013, 68(6): 667-674.

93. Balasubramanian P, Longo VD: Growth factors, aging and age-related diseases. Growth Horm IGF Res 2016, 28: 6668.

94. Virtanen HEK, Voutilainen S, Koskinen TT, Mursu J, Kokko $\mathrm{P}$, Ylilauri MPT, Tuomainen TP: Dietary proteins and protein sources and risk of death: the Kuopio Ischaemic Heart Disease Risk Factor Study. Am J Clin Nutr 2019, 109(5): 1462-1471.

95. Song M, Fung TT, Hu FB, Willett WC, Longo VD, Chan AT, Giovannucci EL: Association of animal and plant protein intake with all-cause and cause-specific mortality. JAMA Intern Med 2016, 176(10): 1453-1463.

96. Tharrey M, Mariotti F, Mashchak A, Barbillon P, Delattre $M$, Fraser GE: Patterns of plant and animal protein intake are strongly associated with cardiovascular mortality: the Adventist Health Study-2 cohort. Int J Epidemiol 2018, 47(5): 1603-1612.

97. Virtanen HEK, Voutilainen S, Koskinen TT, Mursu J, Tuomainen TP, Virtanen JK: Intake of different dietary proteins and risk of heart failure in men: The Kuopio ischaemic heart disease risk factor study. Circ Heart Fail 2018, 11(6): e004531.

98. de Koning L, Fung TT, Liao X, Chiuve SE, Rimm EB, Willett WC, Spiegelman D, Hu FB: Low-carbohydrate diet scores and risk of type 2 diabetes in men. Am J Clin Nutr 2011, 93(4): 844-850.

99. Lagiou P, Sandin S, Lof M, Trichopoulos D, Adami HO, Weiderpass E: Low carbohydrate-high protein diet and incidence of cardiovascular diseases in Swedish women: prospective cohort study. BMJ 2012, 344: e4026.

100. Li SS, Blanco Mejia S, Lytvyn L, Stewart SE, Viguiliouk E, Ha V, de Souza RJ, Leiter LA, et al.: Effect of plant protein on blood lipids: A systematic review and meta-analysis of randomized controlled trials. J Am Heart Assoc 2017, 6(12).

101. Viguiliouk E, Stewart SE, Jayalath VH, Ng AP, Mirrahimi A, de Souza RJ, Hanley AJ, et al.: Effect of replacing animal protein with plant protein on glycemic control in diabetes: A systematic review and meta-analysis of randomized controlled trials. Nutrients. 2015, 7(12): 9804-9824.

102. Campbell TC: A plant-based diet and animal protein: questioning dietary fat and considering animal protein as the main cause of heart disease. J Geriatr Cardiol 2017, 14(5): 331-337

103. Moore LL BM, Singer MR: Beneficial effects of animal and plant proteins on skeletal muscle mass and functional status. Nutrition 2017.

104. Mangano KM, Sahni S, Kiel DP, Tucker KL, Dufour AB, Hannan MT: Dietary protein is associated with musculoskeletal health independently of dietary pattern: the Framingham Third Generation Study. Am J Clin Nutr 2017, 105(3): 714-722.

105. Lukaczer D, Liska DJ, Lerman RH, Darland G, Schiltz B, Tripp M, Bland JS: Effect of a low glycemic index diet with soy protein and phytosterols on CVD risk factors in postmenopausal women. Nutrition 2006, 22(2): 104-113.

106. Davis J, Higginbotham A, O'Connor T, Moustaid-Moussa $\mathrm{N}$, Tebbe A, Kim YC, Cho KW, et al.: Soy protein and isoflavones influence adiposity and development of metabolic syndrome in the obese male ZDF rat. Ann Nutr Metab 2007, 51(1): 42-52.

107. Aoyama T, Fukui K, Nakamori T, Hashimoto Y, Yamamoto T, Takamatsu K, Sugano M: Effect of soy and milk whey protein isolates and their hydrolysates on weight reduction in genetically obese mice. Biosci Biotechnol Biochem 2000, 64(12): 2594-2600.

108. van Nielen $M$, Feskens EJ, Rietman A, Siebelink $E$, Mensink $M$ : Partly replacing meat protein with soy protein alters insulin resistance and blood lipids in postmenopausal women with abdominal obesity. J Nutr 2014, 144(9): 1423-1429.

109. Trujillo J, Cruz C, Tovar A, Vaidya V, Zambrano E, Bonventre JV, Gamba G, Torres N, Bobadilla NA: Renoprotective mechanisms of soy protein intake in the obese Zucker rat. Am J Physiol Renal Physiol 2008, 295(5): F1574- 1582.

110. Genkinger JM, Makambi KH, Palmer JR, Rosenberg L, Adams-Campbell LL: Consumption of dairy and meat in relation to breast cancer risk in the Black Women's Health Study. Cancer Causes Control 2013, 24(4): 675-684. 
111. Farvid MS, Cho E, Chen WY, Eliassen AH, Willett WC: Adolescent meat intake and breast cancer risk. Int J Cancer 2015, 136(8):1909-1920.

112. Fung TT, van Dam RM, Hankinson SE, Stampfer M, Willett WC, Hu FB: Low-carbohydrate diets and all-cause and cause-specific mortality: two cohort studies. Ann Intern Med 2010, 153(5): 289-298.

113. Cross AJ, Ferrucci LM, Risch A, Graubard BI, Ward $\mathrm{MH}$ Park $\mathrm{Y}$, Hollenbeck AR, et al.: A large prospective study of meat consumption and colorectal cancer risk: an investigation of potential mechanisms underlying this association. Cancer Res 2010, 70(6): 2406-2414.

114. Alexander DD, Weed DL, Miller PE, Mohamed MA: Red meat and colorectal cancer: A quantitative update on the state of the epidemiologic science. J Am Coll Nutr 2015, 34(6): 521-543.

115. Soto-Vaca A, Gutierrez A, Losso JN, Xu Z, Finley JW: Evolution of phenolic compounds from color and flavor problems to health benefits. J Agric Food Chem 2012, 60(27): 6658-6677.

116. De Filippis F, Pellegrini N, Vannini L, Jeffery IB, La Storia A, Laghi L, Serrazanetti DI, et al.: High-level adherence to a mediterranean diet beneficially impacts the gut microbiota and associated metabolome. Gut 2016, 65(11): 1812-1821.

117. Koeth RA, Wang Z, Levison BS, Buffa JA, Org E, Sheehy BT, Britt $\mathrm{EB}$, et al.: Intestinal microbiota metabolism of $\mathrm{L}$ carnitine, a nutrient in red meat, promotes atherosclerosis. Nat Med 2013, 19(5): 576-585.

118. Cordain L, Eaton SB, Sebastian A, Mann N, Lindeberg S, Watkins BA, O'Keefe JH, Brand-Miller J: Origins and evolution of the Western diet: health implications for the 21st century. Am J Clin Nutr 2005, 81(2): 341-354.

119. Hildebrandt MA, Hoffmann C, Sherrill-Mix SA, Keilbaugh SA, Hamady M, Chen YY, Knight R, et al.: High-fat diet determines the composition of the murine gut microbiome independently of obesity. Gastroenterology 2009, 137(5):1716-1724.

120. Armougom F, Henry M, Vialettes B, Raccah D, Raoult D: Monitoring bacterial community of human gut microbiota reveals an increase in Lactobacillus in obese patients and Methanogens in anorexic patients. PLoS One. 2009, 4(9): e7125.

121. Cluny NL, Reimer RA, Sharkey KA: Cannabinoid signalling regulates inflammation and energy balance: the importance of the brain-gut axis. Brain Behav Immun 2012, 26(5): 691-698.

122. Leung J, Burke B, Ford D, Garvin G, Korn C, Sulis C, Bhadelia N: Possible association between obesity and Clostridium difficile infection. Emerg Infect Dis 2013, 19(11):1791-1798.

123. Chapman-Kiddell CA, Davies PS, Gillen L, Radford-Smith GL: Role of diet in the development of inflammatory bowel disease. Inflamm Bowel Dis 2010, 16(1):137-151.

124. Mayberry JF, Rhodes J, Newcombe RG: Increased sugar consumption in Crohn's disease. Digestion 1980, 20(5): 323-326.

125. Ananthakrishnan AN, Khalili H, Konijeti GG, Higuchi LM, de Silva P, Fuchs CS, Willett WC, et al.: Long-term intake of dietary fat and risk of ulcerative colitis and Crohn's disease. Gut 2014, 63(5): 776-784.

126. Cani PD, Possemiers S, Van de Wiele T, Guiot Y, Everard A, Rottier O, Geurts L, et al.: Changes in gut microbiota control inflammation in obese mice through a mechanism involving GLP-2-driven improvement of gut permeability. Gut 2009, 58(8): 1091-1103.

127. Magee EA, Richardson CJ, Hughes R, Cummings $\mathrm{JH}$ : Contribution of dietary protein to sulfide production in the large intestine: an in vitro and a controlled feeding study in humans. Am J Clin Nutr 2000, 72(6): 1488-1494.
128. Coffey JC, Docherty NG, O'Connell PR: Hydrogen sulphide: an increasing need for scientific equipoise. Gastroenterology 2009, 137(6): 2181-2182

129. Jowett SL, Seal CJ, Pearce MS, Phillips E, Gregory W, Barton JR, Welfare MR: Influence of dietary factors on the clinical course of ulcerative colitis: a prospective cohort study. Gut 2004, 53(10): 1479-1484.

130. Peng $M$, Bitsko $E$, Biswas D: Functional properties of peanut fractions on the growth of probiotics and foodborne bacterial pathogens. J Food Sci 2015, 80(3): M635-641.

131. Liu H, Zhang J, Zhang S, Yang F, Thacker PA, Zhang G, Qiao S, Ma X: Oral administration of Lactobacillus fermentum 15007 favors intestinal development and alters the intestinal microbiota in formula-fed piglets. J Agric Food Chem 2014, 62(4): 860-866.

132. David LA, Maurice CF, Carmody RN, Gootenberg DB, Button JE, Wolfe $B E$, Ling $A V$, et al.: Diet rapidly and reproducibly alters the human gut microbiome. Nature 2014, 505(7484): 559-563. 